University of Louisville

ThinkIR: The University of Louisville's Institutional Repository

Electronic Theses and Dissertations

1932

\title{
The effects of a special technique upon rate and comprehension in teaching silent reading.
}

\author{
S. Harlan Vogt \\ University of Louisville
}

Follow this and additional works at: https://ir.library.louisville.edu/etd

Part of the Educational Methods Commons

\section{Recommended Citation}

Vogt, S. Harlan, "The effects of a special technique upon rate and comprehension in teaching silent reading." (1932). Electronic Theses and Dissertations. Paper 1936.

https://doi.org/10.18297/etd/1936

This Master's Thesis is brought to you for free and open access by ThinkIR: The University of Louisville's Institutional Repository. It has been accepted for inclusion in Electronic Theses and Dissertations by an authorized administrator of ThinkIR: The University of Louisville's Institutional Repository. This title appears here courtesy of the author, who has retained all other copyrights. For more information, please contact thinkir@louisville.edu. 


\title{
UNIVIRSITY OF LOUISVILIE
}

THE EYFECTS OF A SPECIAL TECENIGUE UPON RATE ANL CCMPREHENSION IN TEACHING SILENT REALING

\author{
A IISSERTAIION \\ SUBMIITED TC THE FACULTY \\ OF THE GRALU TE SCHCOL OF THE UNIVERSIIY OF LOUISVILLE \\ IN PARTIAL FULFILIMENT OF THE \\ REQUIRERENTS FOR THE DFGREE \\ OF MASPER OF ARTS
}

DEPARTMENT OF IIUUCATION

BY

S. HARLAN VCGT

1932 
TABIE OF CONTENTS

LIST OF TABLES AND CHARTS

PAGE

11

CHA PTER

I. INTROLUCTION 1

II. STATEMENT OF THE PROBLEM ANL QUESTIONS 5

III. EXPLANATION OF FHCTORS INVOLVET IN TECHNIQUE 8

IV. A REVIEW OF SOME RECENT INVE TIG TIONS 23

V. MATERIALS AND METHODS 31

VI. SUMMARY AND CONCLUSIONS 41

BIBLIOGRA PHY

APEENUIX $\quad 55$ 
LIST OF TABLES AND CHARTS

TABLE

PAGE

I. COMPARISON OF MEANS OF RAN SCORES, MADE ON VARIOUS TESTS, OF CONPREHENSION OF SI LENT REALTNG IN THE FOURTH, FIFTH, AND SIXTH GRAIES.

II. DIFFEFENCE OF IEANS OF RAY SCORES AID CRITICAL RATIOS OR COIMPREHENSION FOR VARIOUS TESTS IN STIENT REAIING IN THE FOURTH, FIFI', AND SIXTH GRADES.

III. MEANS OF GAINS IN DALE AND CONPREHENSION OF ST TENT READING BUR ING TEACPI'G FERIODS IN THE SIXTH GRADE.

IV. DIFFERENCE IN MEANS OF GAITS AND CRITICAL RHTOS FOR VARIOUS TESTS OF CONEREHENSION AND RATY IN SILENT RFADING IN THE SIXTH GRADE.

V. COMPARISON OF MEANS OF FAM SCORES MADE ON VARIOUS TESTS OF RATE IN SILENT FEADING IN THE FOURTH, FIFT", AID SIXTH GRALES.

VI. IIFFERENCES OF MEANS OF R.W SCORES AND CRITICAL RATIOS OF RAE FOR VARIOUS TESTS OF SILENT READING IN THE FOURTH, FIFTH, AND SIXTH GRALES.

VII. CORREIATION BETNEEN GAINS, MADE IN RATE ANI COMPPEHENSION TESTS IN SI LENT REAIINGG AND THE INTELIIGENCE UOTIENT S OF SIXTH GRADE PUPILS.

CHAR'IS

CHART

I. SHOW ING AGE-IISTRIBUTION OF THE YUFILS IN GRALES IV, V, AND SIX.

II. SHOWING WENTAL AGE-LISTRIBUTION OF PUPILS IN GRADES IV, $\mathrm{V}, \mathrm{ANI}$ VI. 
CHAPTER I 
CHA PTER I

INTRODUCTION

This experiment was undertaken with the object in view of determining whether or not a technique, embracing certain factors, in teaching silent Reading, would result in an increase of speed and comprehension. The experiment was conducted in the fourth, fifth, and sixth grades of the Port Fulton School of Jeffersonville, Indiana, during a period of seventy-five school days.

The factors involved in this technique are:

I. Recognition of the value of the habit of rapid silent Reading;

II. Practice in extensive silent Reading;

III. Formation of habits of proper uniform rhythmical eye movement;

IV. Decrease in vocalization;

V. Time-pressure control.

According to Gates, Reading is both the most 1 mportant and the most troublesome subject in the elementary school curriculum. It is most important since it is a tool, mastery of which is essential to the learning of nearly every other school subject; most troublesome since pupils fail in reading far more frequently than in any other elementary skill.

The importance of reading is indicated in many ways. That teachers and school officers recognize its significance is indicated by the relatively large time allotment and the wealth of 
teaching devices originated for this subject in the elementary school. That those engaged in research realize the importance of reading is apparent in the relatively large number of investigations in this subject that have been made during the last three decades. Both school experience and scientific research have added new evidence of the prime importance of good reading in school work. That spelling is partly dependent upon effective reading, that good methods of study in geography, history, and other subjects are largely due to types of reading techniques, that difficulties in working arithmetic problems frequently result from faulty reading habits; these facts are examples of an increasing number of findings that emphasize the value of establishing good reading habits. ${ }^{1}$

Again, Germane and Germane say the importance of teaching pupils to read effectively can scarcely be overestimated, since reading is the key to all subject-matter. We know that the pupli's progress in school depends largely upon the speed and accuracy with which he can get the thought from the printed page. Judging from the time allotment accorded reading in the grades, it is evident that the importance of this subject has been recognized. In fact, an examination of courses of study shows that in the primary grades approximately 70 per cent of the time has been devoted to the teaching of reading. 90 per cent of a child's reading both in school and out is silent reading. Is it fair to have the child acquire attitudes toward a subject and to form habits and develop slill for which he will

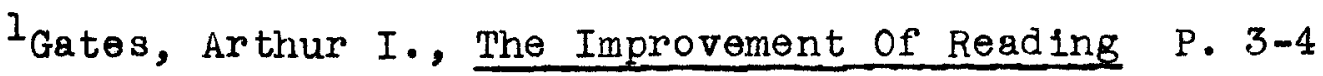


have little use either in school or out of it? The habits formed in oral readirg may be a positive hindrance to the acquirements of speed and comprehension in silent reading. 1 Stone holds that traditional objectives and practices in teaching reading have failed to t ake into account the importance, economy, and efficiency of slient reading, as distinguished from oral reading. The stereotyped oral-reading procedure stresses form and mechanics, whereas the new objective for developing skillful silent reading empiasizes thought-getting under conditions of correct attitudes and motivating purposes. The need for special attention to silent $r$ ading is indicated in the fact that, in the army intelligence tests, approximately one fourth of the young men of the country could not comprehend simple passages of the most ordinary printed material. Numerous surveys with reading tests have revealed the inability of a considerable portion of pupils in the middle and upper grades to do the reading required in their studies. An important general objective in reading is the development of all pupils in skillful silent reading, to the extent of their mental ability. Training in silent reading should aim to improve comprehension in its three fundamental phases: power or depth of comrrehension, quickness or speed of comprehension, and accuracy. 2

"The teaching of slient reading, if it is to be effective, must be based upon clearly defined aims and carefully worked out methods of procedure. It might be inferred that the only objectives of silent reading are a rapid rate and efficiency in

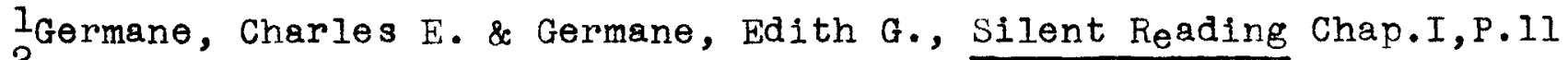
2 Stone, Clarence R., Sllent and Oral Reading, Chap. I, P.4 
reproducing specific points. Silent reading implies much more. It implies above all the ability to react to the materials of the printed page in a critical manner, the ability to use them In the solution of daily problems and for purposes of general intellectual growth. Silent reading and study are, therefore, essentially synonymous. Therefore, training in silent reading implies training in study and training in the use of books. This means of course that training in silent reading should be closely correlated with the work in other subjects. It stresses the necessity of making the reading exercise. specific and purposeful. The continued reading of selections for no other purcose than to restate in general what has been read is at best a questionable practice. For the most part the nupil should read with specific problems in mind, problems which have been defined under the direction of the teacher before the reading begins. The pupll should be judged largely by the speed and the accuracy which he displays in connection with reading of this kind. 1

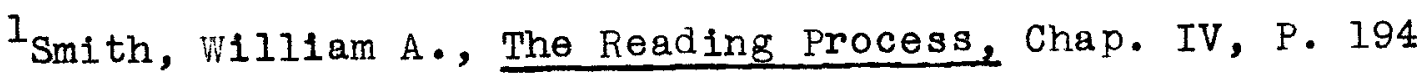


CHAPTER II 


\section{CHAPTER II}

\section{STATEMENT OF PROBLEM AND QUESTIONS}

This experiment, as was stated, was undertaken with the object in view, of determining, if possible, whether or not a technique, embracing certain factors in teaching silent Reading, would result in an increase in speed and comprehension.

What is the significance of this study? Present day social conditions require the need for effective, rapid Silent Reading; reading material is abundant; reading is almost universal, only a few, comparatively speaking, are unable to read; communication is very rapid; the written language is one of the chief means of commication. In fact, success and happiness in life may depend largely upon the kind and scope of one's reading.

In the Port Fulton School, of Jeffersonville, Indiana, where this experiment was conducted, a greet number of the pupils of the fourth, fifth, and sixth grades seemirgly were unable to read as rapidly and as comprehensively as could be desired. The sixth grade especially aroused my interest as they have been under observation since their entrance into the school. They seemed unable to discriminate between the major and minor facts in their studies; they could not read as rapidiy as was sometimes necessary in a crowded curriculum as is ours at the present time. The question then presented itself;Can these boys and girls be trained to better their present rate in speed, and ablilty to comprehend; and if so, how?

Some consideration must be given regarding the type of 
homes from which these children come; did they come from homes where the father was a professional man, business man or laborer? What advantages for reading were given to the boys and girls in these families; did they have access to newspapers and periodicals, was there private library in the home; were they patrons of the Public Library? In short, the economic status of the family should be considered.

Below is a resume in which the children are classified as coming from three types of homes; laboring; business; and professional classes:-

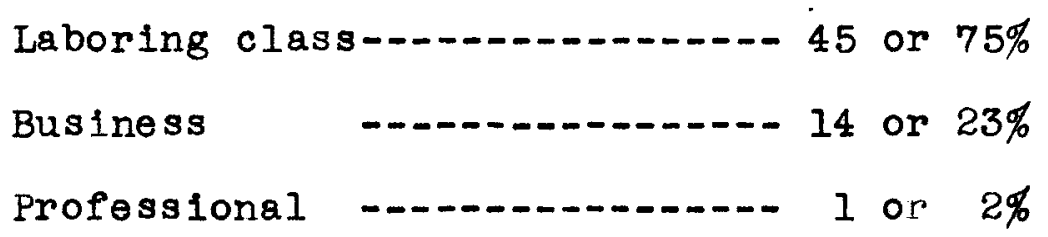

The amount and variety of reading material avallable is shown in the following tabulation:

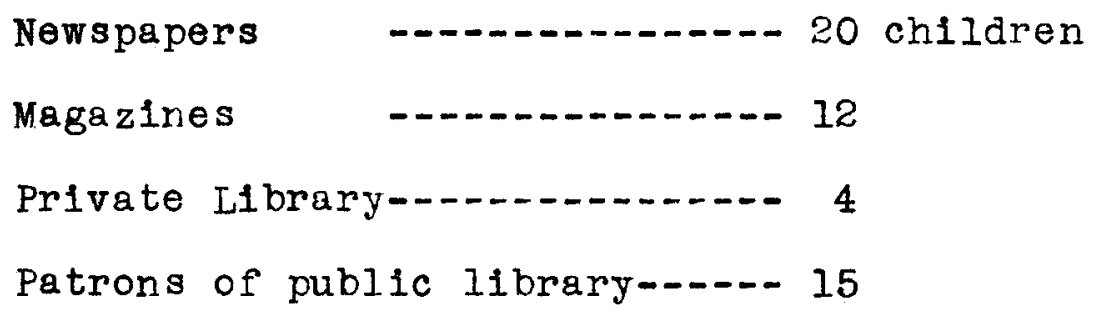

This study was made with these groups inasmuch as such experts, as Charles H. Judd and William S. Gray, and progressive schools generally, have accepted the position that the middle grades form the critical period in developing fundamental attitudes, hablts and skills in silent Reading.

With these statements in mind there follows a number of pertinent questions which this investigation will endeavor to answer:

What increase, if any, in the speed of reading is noted? 
Is the comprehension thereby decreased, unaffected, or increased?

Do the irdividual differences in rate tend to decrease or to become more prominent as a result of training in silent reading?

What grades show the greatest susceptibility, if any, to improvement in rate of silent reading?

How do the present norms for rate of silent reading for fourth, fifth, and sixth grades compare with the norms obtained in this study after training has been given in rapid silent reading?

What are tentative standards for rate for grades in which puplis have been trained in rapid silent reading? 
CHAPTER III 
CHA PTER III

EXPLANATION OF FACTORS INVOLVED IN TECHNIQUE

As previousiy stated the factors involved in the technique used in this experiment are:

(1) Recognition of the value of the habit of rapid silent Reading;

(2) Practice in extensive silent Reading;

(3) Formation of habits of proper uniform rhythmical eye movement;

(4) Decrease in vocalization; and

(5) Time pressure-control.

Each of these factors will be discussed separately, and in Chapter IV a summary of some recent studies will be given, similiar to the one under consideration.

\section{FACTOR I}

In recognition of this factor Germane and Germane ${ }^{I}$ hold that "the pupil's attitude toward reading is very important. If he thinks of the lesson as containing material with which he should become familiar, he will accomplish much more. Psychology has shown the influence of the will when doing a thing. If the pupil desires to become a proficient reader, the methods employed during the class period will be much more effective."

$0 \cdot B r i e n^{2}$ maintains that probably the chief peason why comparatively few readers have acquired habit of rapid silent reading

${ }_{2}^{1}$ Germane and Germane, Silent Reading, Chap. XIII, P. 260 o'Brien, John Anthony, Silent Reading, Chap. III, P. 70-7I 
is due to the fact that they have falled to recogn ize the possibility of greatly increasing their rate. The discovery of the possibility of appreciably accelerating the rate is the result of investigations of comparatively recent date. The knowledge thus gained from these investigations is only beginning to filter through into educational practice and to reach the popular mind. It is necessary that one recognize the possibility of establishing immeasurably more effective and economical habits of rapid silent reading, along with an appreciation of their value, if one is to acquire them. Once these facts have been clearly perceived, the effort necessary to substitute "higher order" habits of reading for slow dawding ones will be readily forthcoming. It is of the utmost importance that both the teacher and the pupils recognize the value and possibility of establishing such habits. Unless the pupils perceive the value of such habits, and are made to feel the need of acquiring them, their reading is apt to be mechanical and lacking that earnestness which is so necessary to effectibe habit formation, and, in fact, to all successful work. On the other hand, if the value of such habits is perceived and the need felt, the successful outcome is already half assured. From such an attitude there springs concentration of mind, enthusiasm, and sustained interest, all of which are so essential in the acquirement of habits of rapid si lent reading.

One must have the determination to read rapidly. The general literature on the subject of reading records several instances of persons suddenly awakening to the realization that their rate was unnecessarily slow. Accordingly they resolved 
rather simply and naturally to bring it up to a higher level. Huey ${ }^{l}$ owed the doubling of the rate largely to his simple determination to "speed up." Indifference to improvement in their habits of reading on the part of puplis may be justly expected to produce indifferent results. According to 0 'Brien ${ }^{2}$ much of the ordinary reading is of the lackadaisical, dead-level, plodding type broken by many gaps of attention and much unconscious day dreaming. He holds that a sudden determination to "speed up" effects a change in the whole mental attitude; it shoots the attention rapidy over the subject matter, and replaces listlessness with spirit and dynamic energy.

Again Germane and Germane ${ }^{B}$ hold that the pupil's attitude toward reading is very important. "If the child thinks of the lesson as containing material with which he should become familiar, he will accomplish much more. Psychology has shown the Influence of the will when doing a thing." If we can get the pupil interested to the point that he wants to become a proficient reader, the methods employed during the class period will be much more effective and conducive of results.

\section{FACTOR II}

In order to develop the proper background of meaning there should be extensive reading of all types of material that give the child valuable experience. The traditional point of view in relation to the reading course for the middle grades has been to have a few well selected units studied intensively, with

$1_{\text {Huey, Edmund B., The Psychology and Pedagogy of Reading, }}$ 2 o'Brien, John Anthony, Silent Reading, Chap. 3, P. 72 3 Germane \& Germane, silent Reading, Chap. 3, P. 260 
oral rendition following minute analysis, The point of view now coming to be more gererally accepted is to have large amounts of reading done in these grades, to provide the pupil with a vicarious type of experience, to develop efficient reading habits, and to develop the habit of reading for recreation. According to Anderson and Davidson ${ }^{1}$ extensive reading increases rate. Wuch reading of simple, interesting material should be provided. The opportunity to read widely increases word mastery and improves reading rate.

In the intermediate grades the reading is extensive, and the emphasis is on thought getting. Since the aim of this reading is both informational and recreational, it should contribute toward the development of a permenent interest in a variety of reading material. The pupil should master the mechanics of reading reasonably well in the primary grades; beginning with the fourth grade his chlef concern should be to improve his power to "husk thought" from the printed page. Silent reading must be stressed more than heretofore. Not only must silent reading seek the thought, but it must strive to get the thought in progressively shorter time.2

$$
\text { Germane insists }{ }^{3} \text { that if we are to develop the child's }
$$
silent reading ability to the utmost, we must give him much practice in reading various kinds of material. We must get rid of the idea that one book contains all that a child should read in a year. We must give him access to an abundance of

IAnderson, Charles J.\& Davidson, Isobel, Reading Objectives, 2 Schmidt, Chap. 6 . 6 P. ${ }^{9} 95$ And Learning The Common ranches, Chap.6, P. 179 3 Germane'sc Germane, Silent Reading, Chap. 10, P. 186 
material which is within the range of his interests and comprehension. Investigations have proven that children need different kinds of reading material if they are to obtain the best results from their work in reading, because the ability to assimilate what one reads depends to a large extent on the nature of the subject matter. There are as many different kinds of silent-reading abilities as there are different kinds of reading materials. No type of material is adequate for teaching silent reading. The greater the supply of kinds of subject matter, the better it is for both teacher and nupil. There are at least four reliable sources of reading material which are available to every teacher: The various school readers, text-books, library books, pamphlets or bulletins. Stone holds ${ }^{l}$ that studies of various types of silent reading indicate the need of training pupils in effective habits of attack in reading different types of content, in reading for different purposes, and in doing analytical study. He further points out that the fourth, fifth, and sixth grades are probably not periods of elaborate analytical study, but that there should be much reading of a variety of material. To the fourth, fifth, and sixth grades, then, may be assigned the task of cultivating fluent silent reading of various types in preparation for later elaborate form of analytical study.

From the above statements it is plain that if one wishes to acquire skill in silent reading, it is necessary that he have aburdant practice in the two principal types of silent reading; 
namely, cursory, unreflective, nonstudious reading and reflective, studious reading.

\section{FACTOR III}

In consideration of the third factor $S_{m}{ }^{i t h}{ }^{1}$ says that contrary to popular opinion, the passage of the eyes across the page is not continuous. He says that it consists rather of a series of movements and stops, the former being commonly designated as interfixation movements and the latter as fixation pauses. He further reminds us that upon reaching the end of a given line the eye returns, by means of the return sweep, to the beginning of the next. The intensive study of these movements and pauses, especially the pauses, has thrown much light upon the nature of the reading process. Again in sneaking of the character of interfixation movements and return sweep he says, "It has boen conclusively established through a long chatn of investigations that the eye can receive no distinct visual impression during the time that it passes from one fixation point to another. All but an insignificant fraction of the time in reading is spent in pauses. It is during these pauses, periods of apparent rest on the part of the eye, that distinct visual impressions are received from the printed page. The pauses constitute, therefore, the period of perception par excellence, though it must be borne in mind always that perception and assimilation as such are continuous processes which proceed essentially uninterrupted by movements and pauses." From the above quotation it is obvious that the number of pauses which an individual requires in reading a line is one of the most

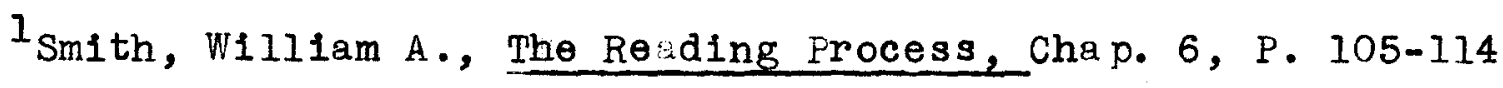


important factors in determining his rate of reading. In general we might say the larger the number of pauses the slower the rate and vice versa. Again $\mathrm{Smith}^{1}$ says that aside from the possible exception, of their number, the duration of the pauses is the most important factor in determining the rate of reading. The shorter the rauses, the more rapid the rate of reading and vica versa. From the above statements it appears that the perception time in the case of a given unit of reading material, such as a line or a paragraph, is the product of the average number and the average duration of the pauses required in reading it.

Stone $e^{2}$ in discussing the importance of eye-movements reminds us that the study of eye-movements has occupied an important place in psychological studies of the reading process from the earliest investigations to the present time. He says that in reading the eye makes a series of quick movements with very brief intervening pauses, the actual reading taking place only during the eye-pause or act of fixation. He further telis us that the number of eye pauses per line varies according to the maturity and efficiency of the reader, the good reader in the upper grades makes as many as fifteen. The better readers not only make fewer pauses, but the eve-movements are of a m ore rhythmical character. The development of the proper eye-movement habits is one of the most important problems in reading.

I Ib1d, PP. 117-18

2 Stone, Clarence R., Silent And Oral Reading. Chap. 2, P. 6 
In commenting on the work of the eye in reading Anderson and Davidson ${ }^{I}$ maintain that a child cannot get thought from his reading unless he has command over the mechanics of reading. They hold that one mechanical adjustment that is essential in both sllent and oral reading is the movement of the eyes along the lines of print. In reading the eye does not move along the lines of print in a steady, even manner, but rather by a series of quick, jerky movements. They say that reading takes place during the fixation pauses which occur between the jerks or sweeps and that the number of fixation pauses is determined by the nature of the material, the purpose for which it is read, and the individual's familiarity with the vocabulary presented.

From the above it is plain that all methods or devices should tax the eye span to the limit; that is, each child should be tralned to see as many words as possible at each fixation pause. All methods or devices should reduce the number of fixations per line, and lessen the time spent on each pause. Further, all methods or devices should increase the tendency to read in rhythmical sweeps by increasing the span of recognition. Since one's rate of reading becomes a fixed motor habit, as difficult to change possibly as any other habit, it is logical to assume that right habits should be established in the early stages of learning to read.

Again Schmidt ${ }^{2}$ says that we have long assumed that the eye moves steadily along the line, from left to right, word by word, as we read. Recently this process has been subjected to experimental study, and it has been found that what really takes place 
1s a succession of rapid eye movements separated by pauses, and that the recognition of words takes place during those pauses. If a finger is laid lightly on the lid of one eye while the other eye is permitted to read, the jerks and stops may be detected. This peculiar eye movement in reading may also be seen by placing a mirror on the left rage of a book and looking over the subject's shoulder while he is reading the right page. The character of these movements and pauses is an important factor in the reading process. An efficient reader moves his eyes rapidly and regularly with only three or four short pauses per line. A poor reader makes several times as mary pauses; and his pauses are longer. The eye movements are frequently regressive as well as progressive. The child who is just beginning to read pauses at every word or phonogram, and makes many regressive or backward movements. With experience in reading, the pauses becme shorter and fewer, and the eye sweeps or movements become longer. When a person's reading habits are formed his eye movements reveal a regular rhythm of movements and pauses, but the rhythm varies with different kinds of subject matter, with different sizes of type, and with different length of lines. Schmidt ${ }^{l}$ further says that one may judge a pupil's reading ability by the character of the eye sweeps, pauses, and regressive movements.

In the discussion of formation of habits of proper uniform eye movements Stone ${ }^{2}$ says that the photographic studies of eye movements of children and adults in reading indicate that visual perception may take place in units of phrases, words,

${ }^{1}$ Schmidt, C.C., Teaching And Learning The Common Branches, Chap.6, P. 182 $2_{\text {Stone, Clarence }}$ R., Silent And Oral Reading, Chap. 2, P.án 
parts of words, or letter by letter. Usualiy immature readers, such as first grade pupils, and slow, laborlous readers of any age, make several eye-fixations in recognizing a word. It is rare for children to recognize more than a word in one eye pause before the third and fourth grade. There is rapid growth in visual perception for both oral and silent reading during the first three grades. In the middle and upper grades the rate of recognition continues to increase, but investigations show the problems in the middle grades is to continue the growth attained in the lower grades in increasing the span of recognition in silent reading.

\section{FACTOR IV}

In considering factor four which has to do with decreased vocalization or inner speech it is necessary that we remember that in silent reading, the vocal organs tend to $\mathrm{produce}$ the words which the mind perceives and synthesizes into a complete sentence. We appear to hear in i malnation what we read silently. In young readers this impulse to vocalization is manifested by movement of lips. Practiced roaders have learned to suppress lip movement despite the ever present activity of the vocal mechanism.

According to Schmidt the importance of inner speech in silent reading depends upon the subject matter and upon our aim in reading 1t. In poetry, for example, rhythm and melody are importunt elements and much of the beauty is lost if we read too fast for this inrer articulation to take place. On the other

${ }^{1}$ Schmidt, c.c., Teaching And Learning The Common Branches, Chap.6, P.183 
hand Schmidt holds that in much of our ordinary reading, it is desirable to gather only the main ideas, and to apprehend these as rapidiy as possible. Further, in this later instance he says that inner speech contributes little; its presence retards the reading and detracts from the thought.

"The expert silent reader does not hear the sonorous sounds of his own volce or experience any muscular tension of the vocal cords as he reads, especially as he reads the literature of information. When one is reading the "literature of power," of inspiration, the kind that should be chosen for much of the oral reading, no doubt he will and should experience a mental pronunclation of the words. But the vast bulk of all our silent reading is of the former kind, and because of this we should strive to bring the printed word and the thought into direct association. The more intimate this association becomes, the less the necessity for the reader to think the reading in terms of oral speech before the thought is obtained. In proportion as he does this he falls short of the ideal of silent reading for ordinary purposes. In all silent reading, the vocal-motor tendency should be reduced to the minimum, because it tends to retard or becloud the thinking. The sentence read should awaken the ideational centers rather than the vocal-motor or the auditory. The words should be made as transparent as is possible; the language series should become subconscious, mechanical; that is, offer the least possible resistance. The great purpose of silent reading is realized whenever the attention is focused 
on the stream of thought rather than on words and phrases."I

In speaking of inner speech in reading Klapper 2 says that because there is an inseparable association between a word and 1ts sound there is always a problem of inner speech. Just as soon as a visual image of a word is recognized in consciousness an auditory image of it arises, and these two prompt an instantaneous verbal motor expression. He further adds that purely visual reading is not normal. We have here, therefore, an explanation of the prevalent practice, in early reading, of lip movement. This method of reading is not acquired by the children; it is the result of the natural tendency to give expression to any idea in the mind. No sooner does the mind become conscious of the meaning of the symbol which it sees than the organs of speech give expression to 1t. Reading without lip reaction is an acquired art, a habit to be cultivated.

Hue $y^{3}$ states that reading without $11 p$-movement is "an acquired habit," the natural thing being to use the lips, as almost all of us do in practice when we come to a difficult place requiring close attention. According to his own observations he maintained that the disappearance of the lip-movement is no indication of the absence of inner speech in reading. In the reading of most people some form of inner speech is present. The problem is not necessarily to eradicate inrer speech entirely, for that may not always be possible or advisable, but to decrease

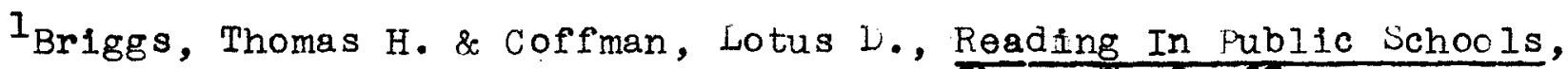
${ }_{3}^{8}$ Klapper, Paul, Teaching Children To Read, Chap. 3, P. 17. 3 Huey, Edmund B., The Psychology And Pedagogy of Reading, Chap. 6 
and abbreviate it until it becomes shadowy, slight and vestigial. Why concern oursel es with the problems of inner speech in reading and mental vs. visual reading? These two questions are important, because they determine a most vital factor in reading as a process of thought-getting, that is, rate in reading. From actual observations we find that there are great discrepancies in the rate of reading among individuals. In other words, it is usual to find among people of the same class, experience, and education individuals who read three or four times faster than others. Generally speaking, the rate in reading is determined by the rhythmic sweeps of the eye over a line; but the rate of rhythic sweeps is, in its turn, modified by inner speech and mental grasp.

\section{FACTOR V}

In discussing the factor of time pressure-control we simply mean that the rate of a pupil's reading is being measured by a clock or watch. O'Brien ${ }^{1}$ holds that the consclousness that he is beirg timed, not only tends to inhibit dawding and daydreaming, but 1 increases the concentration and spurs him on to greater speed. He says that the consciousness of a reliable objective check on any performance serves as a wholesome prophylactic against careless, slovenly, half-hearted work, and provokes the maximum of ability. When the pupil realizes that there is no check upon his performance, no means of determining his rate, there is the tendency for daydreaming and unconscious

${ }^{1}$ 'Brien, John Anthony, Silent Reading, Chap. 3, P. 73-4 
wanderings of the attention to occur. Not that these disturbIng elements are willfully invited, but the mental attitude is such as to offer no strong barrier to their entrance. As mentioned above the consclousness that a clock or watch is accurately measuring the pupil's rate of reading induces a mental "set," which focuses the attention directly upon the task at hand, and which is incompatible both with lackadalsical poring and leisurely dawding. In other words the pressure of a time check serves to "key up" the mind to a superior level of attention, which enables it to devote its whole conscious energy to the gathering of the thought from the printed page and saves it from the necessity of making a fight against irrelevant ideas which tend to draw the attention away from the context. In type of training where speed is one of the qualities aimed at, It would seem that this factor cannot well be omitted. According to Klapper ${ }^{l}$ silent reading, under pressure of limited time, if made a regular part of every reading lesson, brings advantages that are far-reaching and permanent. It not only develops the art of concentration but it trains the eye to be an efficient tool in thought-getting, by subordinating words and symbols to sentences. It also guarantees better oral reading.

As a summary (1) it is recognized that in order to acquire more effective and economical habits of rapid silent reading with an appreciation of their value one must have determination 
to acquire them; (2) much practice in reading various kinds of silent reading material tends to develop the silent reading ability; (3) the development of proper habits of eye movement is one of the most important problems in reading. One may judge the character of a pupil's reading ability by the number of pauses, eye sweeps, and regressive movements; (4) in all silent reading the vocal-motor tendency should be reduced to a minimum as it tends to retard or becloud thinking. The great purpose of silent reading is realized whenever the attention is focused on the stream of thought rather than on words and phrases; (5) silent reading, under pressure of limited time, not only develops the art of concentration but it trains the eye to be an efficient tool in thought-getting, by subordinating words and symbols to sentences. 
CHA VLER IV 


\section{CHAPTER IV}

A REVIEW OF SOME RECENI INVESTIGATIONS

Some similiar investigations dealing with the factors listed In Chapter III have been made and a summary of several of them follow:

The story of how one school system carried out a program of devices for increasing speed and comprehension with marked improvement in reading follows:-

The Thorndike-McCall Reading Scale, Form 2, was used in Grades IV to VIII to discover how the pupils compared in their reading ability with oupils in other school systems. The results showed a decided need of improving speed and comprehension.

There was a general agreement to try to increase speed and comprehension in silent reading by more attentionto the thought and word introduction of the reading lesson, by reading with a definite motivation and a time limit, by overcoming vocalization, by using varied devices for testing understanding and emotional responses, by applying devices for lengthening eyespan, and by having a summary which should cause the child to look back over the reading lesson as a whole before leaving it. In order to measure approximately the gains which they hoped to make, the teachers gave pupils of Grades IV to VIII the Chapman-Cook Speed of Reading Test before inaugurating the program of devices and again at the end of two months' trial of the program. The first test was given on March 28 and showed 32 classes with average scores above the standard for their grades, 
three classes with scores equivalent to the standard, and fifty below the standard.

on June 2, the close of the two months' test period the Chapman-Cook speed of Reading Test ylelded the following results: Out of eighty-five classes, eighty-three showed scores above the standard for their grades as against thirti-two on March 28 , and only two below the standard against fifty below on March 28 . All grades showed an increase in the June 2 over the March 28 score. The amount of increase varied from one point to thirteen points. The gain of 13 points in a fifth grade class represented an increase of 100 per cent. ${ }^{1}$

Rhoads $^{2}$ provided systematic training in comprehension for a group of sixth grade pupils of superior reading ability to determine whether upper grade pup1ls could profit from such training. Remmers and Stalnaker provided training for poor readers at the college level. The results of these and other studies are very gratifying. They indicate that systematic training in important reading habits can often be provided at all levels to advantage. They also show that the achievement of groups of poor readers can be radically improved when appropriate methods of instruction are applied. Hunt ${ }^{4}$ studied two groups of which the intelligence scores

${ }^{1}$ Springsteed, Clara B., Improving Speed and Comprehension In Reading, $2_{\text {Rhoads, Iuke C.,S S tematic Remedial Training for Pupils of Superior }}$ Reading Ability, Elementary School Journa1-

3 Remers, H. H., and Stalnaker, J.M., An Experiment in Remedial Exercises at the College Level School \& Soclety. VOI. XXVIII-IJec. 1928-PP. 797-800

${ }^{4}$ Hunt, C. W., Extensive Reading: A Factor in Developing Reading Ab1lity-School \& Society-VO1 XI (1920) PP. 260-6I 
were virtually the same and found that pupils who read extensively improved more in both rate and comprehension of reading than other pupils. In $1921 \mathrm{Zirbes}^{1}$ divided a second grade class into two sections of approximately equal size. "The pupils of the one section were matched or paired with those of the other section in chronological age, Binet mental age, and reading ability as represented by a composite score on several informal reading tests, the Gray Oral Reading Test and the Courtis Silent Reading Test." During a period of 6 weoks one group recelved carefully planned formal and intensive instruction" in reading. "Extensive, silent, and informal reading experience was provided for the other section. The pupils of the latter section were given the opporturity to choose the material which they read. The teacher also supervised their reading each day, giving to each child such help or encouragement as was needed. The purpose of the experiement was to determine the relative merits of the two types of reading activities, "When the time and other factors were as nearly constant as possible and when each was at its best." Records were kept of the daily progress of the pupils. At the end of two months both groups were retested. An analysis of the descriptive records and a comparison of the test scores revealed the following facts:

The average growth in reading ability was almost identical in both groups, but the upper part of the group which had extensive individual silent reading experiences showed more jm- 
provement or growth than the upper part of the group which had formal instruction. The lower ranges of ability in the informal extensive group evidenced less growth than that registered by pupils in the lower end of the formal-instruction group. There was indeed a sharp division which seemed to indicate that extensive silent reading of new material is neither very interesting nor profitable to pupils who read less than sixty words per minute orally and who make two or more serlous errors per minute or meet with as many difficulties in which they require help.

Conversely, the pupils who read more than sixty words per minute orally with infrequent errors and comparative independence seemed to be retarded by instruction and gained more from extensive reading experiences. While intensive reading experlences, 1 ; $\theta$, review or re-reading were especially valuable in the case of children of slow rate and low ability, they were neither as valuable nor as interesting to children who had passed a certain minimal ability. When children with inadequate ability were merely provided with opportunities to do silent reading without appropriate instruction and supervision, they frequently acquired bad reading habits and attitudes. An elaborate study reported by Paynel in 1930 indicated that it is difficult to measure with accuracy the "perceptual span." The data secured led to the tentative conclusion that difficulty in learning to read does not relate so much to the amount recognized at one fixation as it does to "automatizing Ipayne, Cassie Spencer, The Derivation of Tentative Norms for Short Foposyres in Reading Harvard Monggraphs in Education, 
the right responses. The amount of reading matter which can be responded to accurately appears to depend upon training and to a limited extent upon maturity."

In the school year of 1923-24 Burton ${ }^{1}$ directed a study for the purpose of improving ability in silent reading in grades III to VIII.

Early in the school year pupils were given either the otis Group Intelifgence Test or the Illinois General Intelligence Test, and both the Standardized Silent Reading. Test and the ThorndykeMcCall Reading Scale. For a period of eight weeks pupils were directed in their reading activities, a wide variety of reading material beirg provided.

The results of the study showed that there was marked improvement in practically all the grades.

In the study made by Tinker? in which he studied the relation between eye-movement duration and reading time, he found that "only 5.9 per cent of the reading time was consumed by eyemovements," on the average. This allowed about 94 per cent for pauses. He also found that the ratio between eve-movement duration and reading time bore a constant relationship to the reading attitude, the more careful and analytical the reading between more complex, the reading pauses consumed a relatively greater per cent of the total reading time.

During the year 1923-24 the State Normal School at Indiana, Pennsylvania conducted an experiment in silent reading. Pupils

${ }^{1}$ Burton, Cassie B., Unpublished Master Thesis-Things to vo in teach$2_{\text {Tinker, }}$ ing of Reading-George Peabody Colle for Teachers 1925 Time Psychological Review 35: 385-97 September 1928 
from village and rural schools were arranged in special classes. A group intelligence test was given to each class to get a rough measure of the general ability of the group. The plan was to try for ten weeks to test silent reading, largely as suggestedin the text (Germane \& Germane) supplemented to some extent by suggestions from the teacher, to see how much improvement could be made in comprehension. The children were to read under time pressure control. Then they were to be tested on what they had read. After this there was to be a short drill on phrases and sentences to help the pupils to lengthen their eye span. They were also to be encouraged to do much reading both at school and at home.

At the end of the ten weeks period it was found that the fourth, fifth, and sixth grades had gained as much as is usually accomplished in three years. Every class showed gains in comprehension during the experiment. The gain made would average at least 25 per cent. ${ }^{1}$

Tinker ${ }^{2}$ summarized 110 studies relating to visual appre* hension and perception in reading to determine their nature. He found that there is "a natural tendency to combine the different elements of a visual impression into higher units whenever grouping is possible," also that "word form is a very important factor in word perception and that characteristic word form arises from an alternation of Idominant' letters of letter complexes with 'indifferent' letters." He further holds that

${ }^{I_{\text {Lowry, }}}$ Ellsworth, A Silent-Reading Experiment in Rural and V1llage Schools Elementary School Journal, 26: 42-9. 1925 $2_{\text {Tinker, MIIes A. }}$. Visual Apprehension and Perception in Reading Psychological Bulletin 26: 223-40; April 1929. 
no individual can be classified strictly as an objective type or as a subjective type, nor does any single person read by the ame method in all reading situations. He may read largely by word wholes with certain material, while with more difficult or more unfamiliar material his reading may be largely analytical.

$0^{\prime}$ Brien ${ }^{1}$ conducted an experiment with 1200 children in grades 3 to 8 in 20 schools for a neriod of 39 days. The experiment dealt with methods to increase rate. No measure was taken of the mental ability of the subjects, although the experimental and control groups were appoximately equal in reading ability. Furthermore no measure was taken of the quality of work being done in other school subjects while the children were speeding up their reading habits. The final tests showed large gains in rate for the experimental grades when compared with both the control and norms of the Courtis Silent Reading test. In comprehension the gains were very slight in the experimental groups (.09\%) while the controls showed an average loss $(-.07 \%)$.

What is the significance of these investigations or what relationship do they bear to thjs study?

First - in the studies cited above the persons conducting the experiments have ueed, in their techniques for the study of improvements on rate and comprehension, one or more of the five factors which hive been chosen as a basis for the technique of this study. 
Second - the final analysis of the results obtained by the use of these factors shows, that a noticeable increase can be made, both in speed and comprehension. 
CHAPTER V 


\section{GHAPTER V}

MATERIALS \& METHOD

As has been stated this experiment covered a period of seventy-five deys, plus four days used for testing, viz. - January 22, February 29, April 5, and May 11. The work began Jamuary 22 and ended May 11.

The time was divided into three periods of twenty-five days each, flrst January 25 to February 26, second March 1 to April 4, third April 6 to May 10 inclusive.

The grades were apportioned between two teachers as follows, fourth and beginning section of fifth (twenty-nine pupils) to one, and advanced section of fifth and the sixth (thirty-one pupils) to the other. Both teachers, prior to the beginning of the experiment, adopted ldentical methods of attack, as length of class perlod (thirty minutes); dally time of class period, nine to ten A.M. (thirty minutes devoted to each of the sections A, B, C, and D.); use of same types of tests, reading material, method of attack, etc.

In these grades the ages of the children were of standard level as a group; that is: fourth grade median age was ten years, fifth grade eleven years, and sixth grade twelve years. There were some outstanding exceptions--chlldren who were retarded mentally and consequently whose ages were above the norm; some were accelerated. In the charts on the following page will be shown the age-distribution, both chronological and mental of the pupils in grades IV, $\mathrm{V}$, and VI. 
CHART $\mathbf{I}$.

CHART SHOWING AGE-DISTRIBUTION OF THE PUPILS IN GRADES IV, V AND VI IN THE PORT FULTON SCHOOL OF JEFFERSONVILLE, INDIANA. AGE IN YEARS

\begin{tabular}{|c|c|c|c|c|c|c|c|c|c|}
\hline Grades & 16 & 15 & 14 & 13 & 12 & 11 & 10 & 9 & Totals \\
\hline IV & & & & & & 6 & 12 & 1 & 19 \\
\hline V & 1 & & 1 & 1 & 2 & 9 & 4 & & 18 \\
\hline VI & & & 1 & 3 & 16 & 3 & & & 23 \\
\hline & 1 & & 2 & 4 & 18 & 18 & 16 & $I$ & 60 \\
\hline
\end{tabular}

\section{CHART 2}

CHART SHOWING MENTAL AGE-DISTRIBUTION OF PUPILS IN GRADES IV, V; AND VI IN THE PORT FULTON SCHOOL OF JEFFERSONVILLE, INDIANA.

YEARS AND MONTHS

\begin{tabular}{|c|ccccccccc|c|}
\hline & $6-0$ & $7-0$ & $8-0$ & $9-0$ & $10-0$ & $11-0$ & $12-0$ & $13-0$ & $14-0$ & \\
\hline Grades & $6-11$ & $7-11$ & $8-11$ & $9-11$ & $10-11$ & $11-11$ & $12-11$ & $13-11$ & $14-11$ & Totals \\
\hline V & 2 & 1 & 7 & 5 & 2 & 2 & & & & 19 \\
VI & 2 & 2 & 1 & 4 & 4 & 4 & & 1 & & 18 \\
& & & & 3 & 4 & 9 & 3 & 2 & 2 & 23 \\
\hline
\end{tabular}

MEDIANS-

Grade IV - 8 years - 8 years, 11 months

Grade V - 10 Jears

Grade VI - 11 years..- II years, 11 months. 
The materials used, in this experiment, in dally work and testing, included (a) text books

Grade IV.

$$
\text { Wide Awake Reader- Murray }
$$

Grade V

Bolenius Fifth Grade Reader- Bolentus

Grade VI

Thought Study Readers- Spencer, Gans, and Fritschler

(b) Supplementary Materials-

(I) Booklets: ${ }^{1}$

$$
\begin{aligned}
& \text { Story of Peter Cooper } \\
& \text { What Happened at the Zoo } \\
& \text { Story of Bryant } \\
& \text { A Dog of Flanders } \\
& \text { David Crockett } \\
& \text { Children of the South Lands } \\
& \text { Lady of the Lake } \\
& \text { Patrick Henry } \\
& \text { Stories of the Backwoods } \\
& \text { Selections from Wordsworth } \\
& \text { Horatius and other Poems } \\
& \text { Story of Father Hennepin } \\
& \text { Paul Hamliton Hayne } \\
& \text { Great European Cities }
\end{aligned}
$$

${ }^{1}$ These booklets can be purchased in any quantity at nominal cost from the F. A. Owen Publishing Co., Dansvilie, N. Y. 


\section{American Naval Heroes}

Louisa M. Alcott

A Tale of the White Hills

(c) Tests ${ }^{1}$

(I) National Intelligence Test

(2) Detroit Reading Test. (Test III, Forms $A, B, C$, and D.)

On January 22 all the children in grades IV, V, and VI were given the National Intelligence Test and the Detroit Reading Test-Form A. 2

During the first period of twenty-five days, January 25 to February 26, silent reading was taught in this school very much in the same manner as is used in a large number of schools which have not made a special study of modern methods of teaching the subject. This criticism is not made adversely, but merely as a statement of a known fact. The method used was generaliy of the following nature:

At the beginning of the class period pupils were told to prepare for silent reading. Text books, which each child kept at his desk, were opened at a certain page, the teacher speakIng in some such words as these: "Today we are to study a selection by Ernest Thompson Seton. It might be well to learn more about the author and other articles or selections he has written. One book which would interest you is Wild Animals I Have Known'. The title of our selection is 'The Banded Death'.

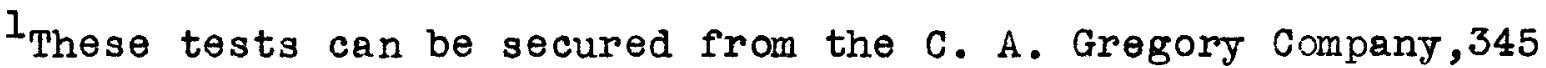
Calhoun Street, Cincinnat1, Oh10.

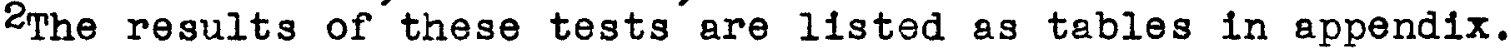


What is 1t? Why was it so called? Who are the actors? What do you consider the most exciting part? Be sure to use the dictionary or the glossary at the end of the selection, for words you don't understand. Let us begin to read."

The selection usually was short enough to be read in approximately fifteen minutes; with the preliminary remarks this covered about two-thirds of the class period of thirty minutes. However, if the selection was too long to be read in this time a stopping place was designated, the remaining time, If any, was used for discussion.

On February 29, at the end of the first twenty-five day period the Detrolt Reading Test, Form $B$ was given. (Results Ifsted as tables in appendix.)

March 1, marks the beginning of the second twenty-f1ve day perlod which ended April 4, during which period the new technlque was used.

At the beginning of the first lesson the children were given a short talk in which the teacher told the pupils that a new plan of study was to be tried for the next few weeks. At this time mention was made of the advantages to be galned of Increased ablitty in rapid reading, especially in preparation of assignments in such subjects as history, geography, etc., and that later, in high school and college where assignments are increasingly long, such ablitty is invaluable; that much reading tends to increase reading abllity; that proper habits of eye movement must be formed; that lip reading must be reduced, and if possible, abolished, and finally that reading under a time limft tends to make for more effective reading. 
Every effort was made to enlist the whole hearted cooperation of the pupils. Charts, which had been prepared previously, were then distributed and pupils were instructed as to their use. These charts were to be used to show the pupil his daily rate in silent reading. The deily procedure was as follows: Reading material was distributed at the beginning of the period, and careful directions were given as to the beginning point. Difficult words were explained in order that the child might not be delayed, annoyed or handicapped after he had begun to read.

Motivation was provided by questions, the type of material determining the kind and number of questions asked: questions tending to arouse curlosity about some part of the story, or some character in the story. Sometimes questions were written on the blackboard and children were told to read for the answers. In substance these words were used: "Read this as fast as jou can when the word 'Go' 1s given. See how much jou can read in two (or three) minutes but remember, you are to tell what you have read, so don't skip anything. When the word 'Stop' is given, mark the last nord read."

After ascertaining that all the children understood what was required and that all were in readiness, the word "Go" was given and all began to read. At the expiration of two minutesl the signal was given to stop and all pupils checked the last a relapse into the customary leisurely reading rate. 
word read. They were then asked to reproduce what they had read, the method of testing varying--depending upon the type of material read; the methods used were: (1) Answering questions placed on blackboard at the beginning of the class period; (2) finding answers to questions that require the organization of the thought of several sentences, paragraphs, or even pages; (3) finding tities to paragraphs; (4) outlining; (5) oral reproduction of the story; (6) dramatization.1

In a similar manner reading and reproduction were continued t1li the end of the thirty minutes assigned. (Exception, One period, per week, of ten minutes was devoted to flash cards and an occasional five minute period was used for a reproduction of the material read in the booklets.)

As a part of the teacher's preparation for the exercise, the average number of words per line and the number of IInes por page, in the material read was computed. From the pupil's report as to the pages and lines read the number of words were estimated, as well as the number read per minute. Each pupil determined his own score and entered it immediately upon his chart, which served as a record of his dally progress in silent reading.

As an incentive for practice in extensive silent reading, booklets were distributed at various times, at the beginning of the class period. Puplis were not tested for rate, as each was told that he could read as many as he wished, but that he would be asked to reproduce what he had read. The number of 
booklets read, per pupil, varied as will be shown by table in the appendix. Other sources of reading were mentioned; newspapers, periodicals, and library books were recommended and pupils were urged to make use of this material. Because of the lack of technical equipment the teacher was handicapped in the attempt to measure eye-morement. However pupils were informed of the necessity of increasing the span, and the elimination of regressive movements. As an aid, flash cards were used. These cards containing words and phrases, of increasing length, progressively, were used once each week for a period of ten minutes.

Efforts to overcome vocalization in sllent reading were carried out by means of the following devices:

(1) Explanation of the disadvantages of vocalization in slient reading;

(2) Emphasis upon silent reading until word symbols become subordinate to the thought as a whole;

(3) Having the chlld exert a definite effort to read more rapidly, and

(4) Having children place a finger over the lips until a decrease in vocalization becomes habitual.

The period of two (or three) minutes in silent reading acted as a safeguard against fatigue, as well as against a relapse into customary lelsurely reading rate.

On April 5, at the end of the second twenty-five day perlod, the Detrolt Reading Test, Form $C$, was given. (The results are listed in tables in appendix.)

April 6, was the beginning of third period of twenty-five 
days which ended May 10. During this perlod the technlque used was similar to that used in the first twenty-five day period. On May 11, the Detrolt Reading Test, Form D, was given. (The results are listed in tables in appendix.)

It would be well to call attention to the fact that these methods of teaching are not used today, 1931-1932, in progressive schools or school systems. I do not mean to imply that our schools are not progressive. Indeed, they have made rapid strides in the past decade. But we are governed to a great degree by the recommendations of our State Board of Education and are required to follow them as closely as possible.

In the Port Fulton School, the teacher load, coupled with an over crowded curriculum and lack of provision for spectal pupils (i.e. retarded or accelerated) probably has had a tendency to minimize the efficlency of the new technique. Possibly, due to the same reasons, the newer method (1.e.,project) could not be used advantageously.

In the newer method today, children are taught by projects; children are taught to read because of the destre to read, rather than for the desire to satisfy the requirements for a formal reading lesson.

As a final statement,--of the five factors used in the new technique, only one, the formation of habits of proper rhythmical eye movement, has given any decided dissatisfaction. The difficulty of measuring the results of this factor, lay, as was previously mentioned, in the lack of proper equipment. The response to the new technique, both by teachers and pupils was most gratifying---the lively interest created being manifest 
In the spirit in which it was received and in the results shown in tables listed in Chapter VI. 
CHA PTER VI 


\section{CHAPTER VI}

SUMMARY AND 00 NCLUSIONS

A brief review or summary of the findings of this study, with conclusions regarding them may be stated in answering the following questions previously mentioned in Chapter II;

Is the comprehension thereby decreased, unaffected, or increased?

Do the individual differences in rate tend to decrease or to become more prominent as a result of training ir silent reading?

what grades show the greatest susceptibility, if any, to improvement in rate of silent reading?

What increase, if any, in the speed of reading is noted?

How do the present norms for rate of silent reading for fourth, fifth, and sixth grades compare with the norms obtained in this study after training has been given in rapid silent reading?

What are tentative standards for rate for grades in which pupils have been trained in rapid silent reading?

As stated before the experiment consisted in conducting the classes, composed of fourth, fifth, and sixth grade pupils, through three different periods under study, the first period in which the old method of teaching silent reading was used, started with test $A$, and term nated with test $B$; the second period began with test $B$ and ended with test $C$. This was the period during which the Experimental method of teaching was used, and this will be referred to hereafter as the Experimental period. During the last period the old 
teaching procedures were followed. This period was considered as starting at the time test 0 was given and terminating with test I. It will be noted that the first period, test $A$ to test $B$ and the last period, test $C$ to test $I$ are the control periods, and are the periods which will be compared with the Experimental period. Table 1 shows the means of raw scores for comprehension of reading which were obtained by varicus tests during different periods. It will be noted also that for the sixth grade very peculiar results were obtained for the first and third periods; i.e., arparently the children not only did not gain In comprehension during these periods but actually seem to have lost, as is indicated by the comprehension score of $15.34 \pm .7$ on test $A$, and mean raw scores $13.26 \pm .74$ on test $B$. On test $C$ the mean score was $18.1 \pm .74$ and on test 1 the mean score was $16.83 \pm .72$.

TABIE. I.

COMFARISON OF MEANS OF RAW SCORES, MADE ON VARIOUS TESTS OF COMPREHENSION OF SILENT REAIING IN THE FOURTH, FIFTH, AND

SIXI'H GRALES OF IFE PCRT FULTON SCHOOL, JEHFEKSOIVILLE, INDIANA.

\begin{tabular}{|c|cccc|}
\hline \multirow{2}{*}{ GRADES } & \multicolumn{5}{|c|}{ MEAN SCORES FOR COMPREHENSION } \\
\cline { 2 - 5 } & TEST A & TEST B & TEST C & TEST D \\
\hline \multirow{2}{*}{ VI } & $15.34 \pm .70$ & $13.26 \pm .74$ & $18.1 \pm .74$ & $16.83 \pm .72$ \\
V & $8.77 \pm .8$ & $9.78 \pm .67$ & $11.78 \pm .91$ & $11.45 \pm .77$ \\
IV & $4.97 \pm .45$ & $6.07 \pm .56$ & $7.97 \pm .59$ & $8.1 \pm .65$ \\
\hline
\end{tabular}


These arrarent losses are shown in Table II where the difference of means for tests $A$ and $B$ is $\pm 2.08 \pm .7 .02$, and the difference between the means for tests $C$ and $D$ is $-1.3 \pm 1.04$. The large $P$. E. in both of the cases indicates that they are not reliable. This lack of reliability is further indicated in the table giving the critical ratios as 2 and 1.2 respectively. These ratios should be at least 3 to bear any reliability.

TABIE II.

DIFFE ENCES OF MEANS OF RAW SCORES ANL CRTTJCAI RATIOS OF COMPREHENSION FCR VARIOUS TESTS IN SITENT REALING IN THE FCURTH, FIFTH, AND SIXTH GRALES. OF THE PCRT FULTCN SCHOCL, JEFEERSONVILTE, INIIAIA.

\begin{tabular}{|c|ccc|ccc|}
\hline \multirow{2}{*}{ GRALE } & \multicolumn{3}{|c|}{ LIFFERENCF OF NEANS } & \multicolumn{3}{c|}{ CRITICAI RATIO } \\
\cline { 2 - 7 } & IEST A\&B & TEST B\&C & TEST C\&D & TEST A\&B & TEST B\&C & TEST C\&D \\
\hline \multirow{2}{*}{ VI } & $-2.08 \pm 1.02$ & $4.9 \pm 1.05$ & $-1.3 \pm 1.0$ & 2 & 4.6 & 1.2 \\
V & $1.01 \pm 1.07$ & $2 . \pm 1.13$ & $.33 \pm 1.19$ & .93 & .17 & .27 \\
IV & $1.10 \pm .72$ & $1.90 \pm .81$ & $.13 \pm .87$ & 1.53 & 2.33 & .148 \\
& & & & & & \\
\hline
\end{tabular}

If instead of taking means of raw scores we consider the means of the gains in comprehension of individual punils we find a similiar situation for grade six, as indicated by table V. 
TABLF III.

MEANS OF THE GAINS IN RATE AND COMPREHENSION OF SILFNT HEADING DURING DIFFEKENT TEACH ING PERIODS IN THE SIXTH GKADE OF THE PORT FULTON SCHOOL, JEFFERSOAVILE, INLIANA.

\begin{tabular}{|l|c|c|}
\hline \multicolumn{3}{|c|}{ MEAN GAINS } \\
\hline TEACHING SITUATION & RAIE & COMIREHENSION \\
\hline 1. IST 25 LAY PEIYIOD & $-1.13 \pm .52$ & $-2.17 \pm .31$ \\
2. 2ND 25 DAY PERICD & $32.17 \pm .36$ & $4.33 \pm .34$ \\
3. 3RD 25 DAY PERICD & $-.98 \pm .66$ & $-.523 \pm .345$ \\
4. AVERAGE 1 AND 3 & -1.41 .419 & $-1.35 * .196$ \\
\hline
\end{tabular}

On the other hand, Table I indicates a real difference between the means at the beginning and at the end of the Experimental period, these means being $13.26 \pm .74$ and $18.1 \pm .74$. Table II gives this difference $4.9 \pm 1.05$, and when comrared with the $F$. E. of the difference of the means gives a critical ratio of 4.6 , which Indicates a real difference, in this case a real increase. These results indicate without doubt, a far as the sixth grade is concerned, that the Experimental method of teaching produced much better results in reading comprehension than were obtaired during the two control reriods. This conclusion is strengthened by the results given in Table IV where the critical ratios for the difference of gains in comprehension are comrared--comnaring the first control period with the Experimental period, the second control period with the Exrerimental reriod. All critical ratios are so large that there is no question about the existence of a real difference. 


\section{TABLE IV .}

LIFFERENCE IN WEANS OF GAINS AND CFITICAL RATICS FOR VARICUS II STS OF COMPREHENSI N ARD RATE IN SILENT READ NNG IN THE

SIXTH GRALE OF THE PORT FULTON SCHOCL, JEFFERSONVILLE, INIIANA.

GRADE VI.

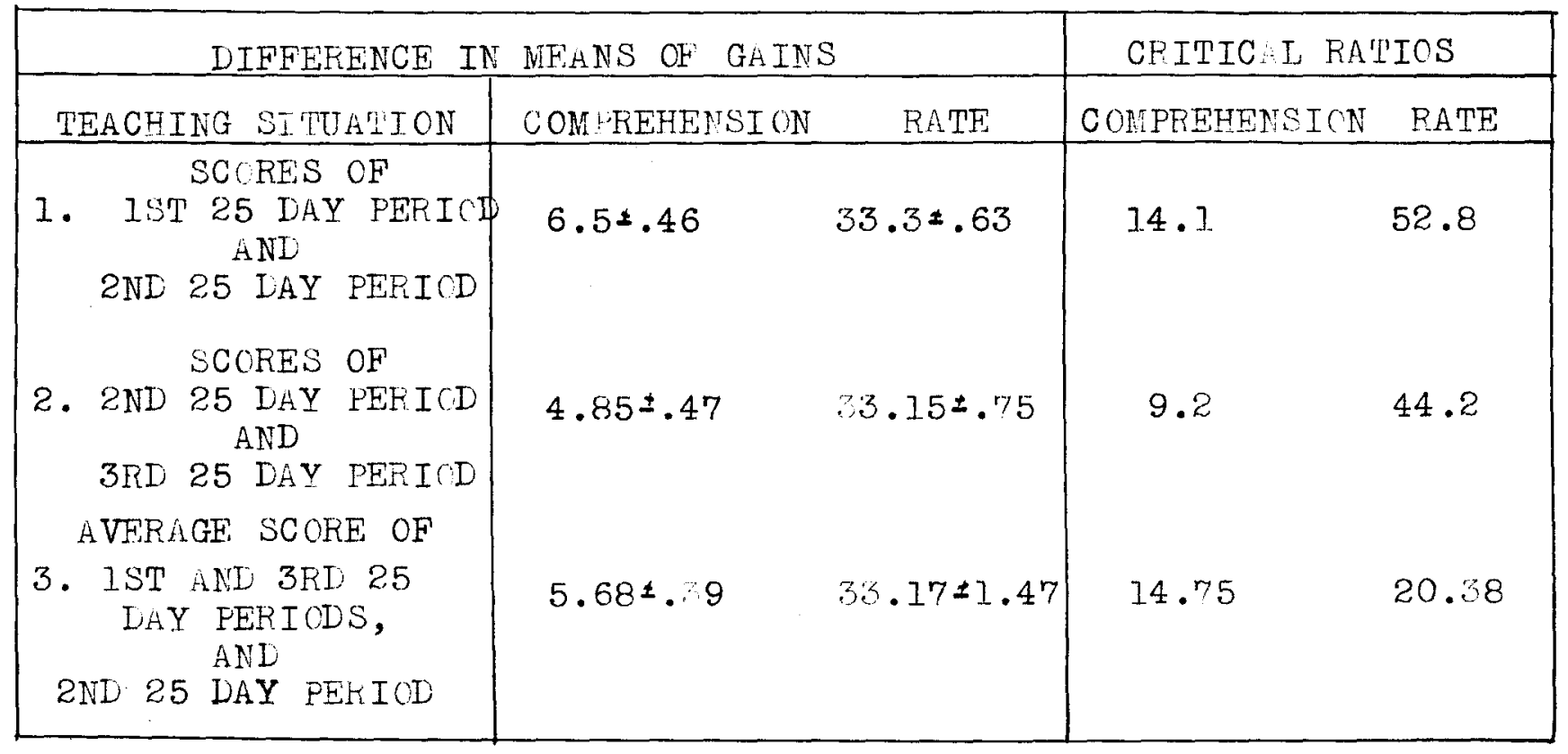

For the fifth grade we find somewhat similiar c nditions. However, the means of the raw scores and the critical ratios of the comprehension of the various study periods reveal the fact that the results a e so erratic as to be of little value in determining anything definite regarding the relative merits of the several teaching situations. In fact, none of the critical ratios are as much as urity. It, therefore, seems that neither the Experimental method nor the methods used for the control periods have proved valuable so far as comprehension is concerned. In fact, the smallest critical ratio is obtained for the Experimental period. If this is an indication then the $\checkmark$ fifth grade is proven to be the least susceptible to imrrovement 
in comprehension under the experimental method.

The metrod of means of gains was not used for grades four and five because the results of the sixth grade inddcate that nothing new is revealed by the use of this techniaue. It is interesting to note, however, that there were apparent gains $\checkmark$ in comprehension during all three periods studied, although the P. E. of differences are so large compared with the difference of the means that the existence of real positive differences are questionable.

Results similiar to those obtained for the fifth grade were found in the fcurth grade. Here again Table II indicates apparent gains with comparatively high $P$. $E$. of differences in all study periods except that the critical ratio of the Experimental period is 2.33 which would lead one to believe that for this period at least there was a real gain in the comprehension of reading.

In rables $V$ and VI will be found data concerning the rate of silent reading. For the sixth grade there seems to have been improvement in this respect during each of the periods studied. This is especially true during each of the Experimental periods where the increase amounted to 28 , and the $P$. E. of difference to 3.6 which is large enough to be sure that a real difference does exist. It is surprising to note that during the two control periods there were practically no gains in the rate of reading. In fact, if we use the method of comparing means of gains these results are negative for tine 
first and second control periods as well as for the average of these two periods, while for the Experimental period the mean gain in rate was $32.17 \pm .36$. Moreover, the critical ratios, given in Table IV where the two control periods are compared to the Experimental period and the average of the results of the controlled periods are compared to the Experimental period, are so large that there is no question of a real advantage in favor of the Experimental period.

\section{THBLE V}

COMPARISON OF MEANS OF RAY SCORES MADE ON VARIOUS TESTS OF RATE IN SILENT RE $\triangle$ DING IN THE FOURTH, FIFTH, AND S XTH GRADES OF THE PORT FULTON SCHOCL, JEFFERSO VILIE, INDIANA.

\begin{tabular}{|c|ccccc|}
\hline \multicolumn{5}{c|}{ MEAN SCORES FOR RATE } \\
\hline GRADE & TEST A & TEST B & TEST C & TEST D \\
\hline VI & $112.9 \pm 3.13$ & $113 . \pm 4.07$ & $141 \pm 6.61$ & $143 \pm 6.87$ \\
V & $94.4 \pm 4.65$ & $90 \pm 3.74$ & $100.56 \pm 4.28$ & $101.66 \pm 4.64$ \\
IV & $71.3 \pm 4.95$ & $75 . \pm 5.02$ & $88.3 \pm 460$ & $88.2 \pm 4.14$ \\
\hline
\end{tabular}

The fifth grade again seems to be less susceptible to improvement in rate of silent reading than the sixth grade. Table $V$ shows that during the two control reriods there was practically no gain in the rate of reading. In fact, during the first perlod there seems to have been a loss, as the critical ratio is so small in both cases that it is aifficult to determine exactly what did take place. There seems to have been a in during the Experimental period as indicated by a difference means of raw scores amounting to 10.56 with a critical ratio of 1.86 . This 
critical ratio is not large enough to be absolutely sure that there was a gain, however it is possible that there was a gain. Although the results for the fourth grade inicate gains in the rate of silent reading for all the periods studied, only during the Experimental period was the gain enough to be considered a real gain. In fact, there might be so me doubt of real improvement having been made during this period. There is no question, however, about the fact that the Experimental method has proved more effective than the method used in the control periods. This is interesting because in the second control period the pupils started with a fuller background than that which they had at the beginning of the Experimental period.

\section{TABLE VI.}

LIFFEEENCES OF NEANS OF RAW SCORES AND CRITICAL RATIOS OF RATE FOR VARICUS TESTS OF SILENT READING IN THE FOURTH, FIFTH, AND SIXTH GRADES OF THE PORT FULTON SCHO L, JEFEERSON VILIE, INDIANA.

\begin{tabular}{|r|llll|lll|}
\hline & \multicolumn{3}{|c|}{ DIFFELENCE OF MEANS } & \multicolumn{3}{c|}{ CRITICAL RATIOS } \\
\hline GRADF & TEST A\&B & TEST B\&C & TEST C\&D & TEST A\&B & TEST B\&C & TEST C\&D \\
\hline VI & $.1 \pm 5.13$ & $28 \pm 7.76$ & $2 \pm 3.6$ & .019 & 3.8 & .21 \\
V & $4.4 \pm 5.96$ & $10.56 \pm 5.57$ & $120 \pm 6.3$ & .73 & 1.86 & .174 \\
IV & $3.68 \pm 7.05$ & $13.3 \pm 6.81$ & $.1 \pm 6.18$ & .52 & 1.96 & .016 \\
\hline
\end{tabular}

As it was for comprehension it seems that the Experimental method has proved more effective for rate of silent reading in the work 
with the sixth grade pupils tran either fourth or fifth grade pupils, although there does not seem to be quite such a larse difference for the results obtained in the varicus grades in rate of silent reading as there was in corprehensinn in silent reading. While there is not much difference in the critical ratios for the fourth and fifth grades there is a slight advantage in favor of the fourth grade as far as the rate of silent reading is concerned. It therefore seems that the sixth grade, in this experiment, has proved the most susceptible to the method used, the fourth grade next, and the fifth grade least, for both rate and comprehension of silent reading.

In Table VII are given correlations between the Intelligence Quotients and the gains made by the various purils of the sixth grade, first during the cortrol period, and second during the Experimental period. It will be observed, both for rate and comprehension that the correlation of the test scores with the Intelligence Quotients is practic lly zero during the first perlod. Moreover, during the Experimental period the corielation of the scores for comprehension seem to bear no definite relaticn to the Intelligence quotients. The scores on rate do seem to be very closely in line with the Intelligence Quotients, as indicated by a correlation of $.93 \pm .018$.

\section{PABLF, VII}

CORRELATICN BETWEEN GAINS, MADE IN RATE AND CONPREHENSION TESTS IN SILENT REAIING, AND THE, INTELLIGENCE QUOTIENTS OF SIXTH GRADE PUPILS TESIED IN PORT FULTON SCHOCL, JEFHERSCNVILIE, INDIANA.

\begin{tabular}{|c|c|c|}
\hline \multirow{2}{*}{ TESTS } & \multicolumn{2}{|c|}{ CORRELATION WITH INTELIIGENCE OUC TIENTS } \\
\cline { 2 - 3 } & RATE & COMPREHENSION \\
\hline A AND B & $.18 \pm .135$ & $-.122 \pm .002$ \\
B AND C & $.93 \pm .018$ & $.214 \pm .1 .4$ \\
\hline
\end{tabular}


This would indicate that at least as far as the rate of silent reading is concerned the Experimental method is well adapted to meet the demands of the individual differences of children. These results do not show that the same is true for comprehension. The P. E. of means of raw scores for comprehension as given in Table I under test $C$ shows that if there is any difference at all, the Experimental method probably reduces, more than the method used in either of the control groups, the differences between the attainments of the individual pupils.

The data is Table $\mathrm{V}$ show that the same situation prevails for rate, though not quite so marked.

A comparison of the norms found by Gray, Starch, and Courtis and the norms found as a result of this exneriment are shown in the table below.

$$
\text { Fourth Grade Fifth Grade Sixth Grade }
$$

$\begin{array}{lrrl}\text { Starch } & 144 & 168 & 192 \\ \text { Gray } & 180 & 204 & 216 \\ \text { Courtis }^{1} & 145 & 168 & 191 \\ \text { Experimental } & 88 & 100 & 141\end{array}$

Though the scores, attained by the puplis, in this study are considerably lower than the norms given by Courtis, Gray, and Starch it will be observed that Gray's norms are considerably higher than those given by Starch or Courtis. It therefore seems quite likeIy that if these pupils are given training like that used during the Experimental period they will be able to approach, rather closely the norms presented by these writers.

This investigation seems to reveal the fact that although 
rupils may read more rapidy there is no definite indication that they comprehend equally well what they read. The results of this experiment might lead one especially interested in the subject to conduct a similiar experiment, but takirg comprehension as his subject of investigation. That factors, other than those used in this new technique could be evolved, which might produce results similiar to those for rate in this investigation; further, what results might be obtained by using this same technique with pupils of high intelligence quotients. Would there be the same upward trend in rate as evidenced by the results of this experiment with a correspondin lack of acceleration in comprehension?

${ }^{1}$ Copied from the Class Record Sheet for the Courtis Silent-Reading Test. 



\section{SELECTED BIBLIOGRA FHY}

I. Method Texts

Anderson, Charles J., and Davids on, Isobel, Reading Objectives. New York; Laurel Book Co., 1925.

Briggs, Thomas H., and Coffman, Lotus I., Reading in Public Schools. Chicago; Row, Peters on and Co., 1908

Brooks, Fowler D., The Applied Psychology of Reading. New York; D. Appleton and Co., 1926.

Gates, Arthur I., The Improvement of Reading. New York; The Macmiliañ Co., 1929.

Germane, Charles E., and Germane, Edith G., Silent Reading. Peterson and Co., 1922.

Huey, Edmund Burke, The Psychology and Pedagogy of Readirg. New York; The Macmilian Co., 1920.

Klaprer, Paul, Teaching Chlldren to Read. New York; D. Appleton and Co., 1922.

O'Brien, John Anthony, Silent Reading. New York; The Macmillan Co., 1926

Parker, Samue? Chester, Types of Elementary Teaching and Learning, New $Y_{0} r k ; G i n n$ and Co., 1923 .

Reeder, Ward G., How to Write a Thesis. Public School Publishing Co., Bloomington, Illinois, 1930

Schmidt, C.C., Teaching and Learning the Common Branches. New York; D. Appleton and Co., 1929.

Smith, Wiliam A., The Reading Process. New York; The Macmillan Co., 1923 .

Stone, Clarence R., Sllent and Oral Reading. New York; Houghton Mifflin Co., 1926.

Wheat, Harry Grove, The Teaching of Reading. Boston; Ginn and Co., 1923.

Williams, J. Harold, Elementary Statistics. New York; D. C. Heath and Co., 1929. 
II. Yearbooks and Reports of Research Studies.

Burks, Jesse I., and Stone, Clarence K., "Relative Effectiveness of Two Different Plans for Training in Silent Reading." Elementary School Journal 29;431-36, Feb. 1929.

Burton, Cassie L., An Experiment in Silent Reading. Master's Thesis. George Feabody Coliege for Teachers, Nashville, Tenn., 1924-25

Buswe11, Guy T., An Experimental Study of the Eye-Voice Span in Reading. Supplementary Educational Wonographs, No. 17. Department of Education, University of Chicago, June 1925.

Gray, W. S., Summary of Investigations Relating to Reading. Supplementary Educational Monographs, No. 28, Department of Education, University of Chicago, June 1925

Hunt, C. W., "Extensive Feading: A Factor in Developing Reading Ability." School and Society, Vol. 2, June 1920.P.475-78

Judd, Charles H., Feading: Its Nature and Development. Supplementary Educational Monographs, Vol, 2, No. 4, Department of Education, University of Chicago, 1918.

Lowry, ElIsworth, "A Silent Reading Experiment in Rural and Village Schools." Elementary School Journal 26: 42-9, Sept. 1925 .

Neal, E. A, and Foster, I., "Program of Silent Keading." Elementary School Journal 27: 275-80, Dec., 1926.

Payne, Cassie spenser, The Lerivtion of Tentative Norms for Srort Exposures in Reading. Harvard Monographs in Education No. 10, Cambridge, Mass. Harvard University Press, 1930

Remmers, H.H., and Stalnaker, J. M., "An Experiment in Remedial Exerclses at the College Level." Schol and Society. Vol. 28, December, 1928. P. 797-800.

Rhoads, Luke C., "S stematic Remedial Rraining for Pupils of Superior Keading Ability." Elementary School Journal. 29: 771,73 , June 1929

Springsteed, Clara B., "Improving Sneed and Comprehension in Reading." Journal of Educational Method 5: 48-52. oct. 1925 .

Tinker, Miles A., "Visual Apprehension and Perception in Reading." Psychology Bulletin 26: $223-4$, April 1929. 
Twentieth Yearbook of the National Society for the Study of Education. Report of the National Committe on Silent Reading. Blo omington, Illinois. Public - School Publisning Co., 1921.

Twenty-Fourth Yearbook of the National. Society for the Study of Education. Report of the National Committee on Reading. Bloomington, Illinois; Public School Publishing Co., 1925 .

Zirbes, Laura and Gray, Wil' lam Scott, "Readirg in the Intermediate Grades." Class Room Teacher, Vol. 6, Chap. 6, P. 204-5.

Williams, Ralph R., "Extensive Reading versus Intensive tudy of Lite ature." School Review 37:666-78, Nov. 1928.

7irbes, Laura, "Silent Reading in the Primary Grades Elementary Schoc 1 Journal" Vol. 26-1926 PP. 578-79 

55

RAW SCORES AND GAINS OBTAINED BY THE DETROIT READING TEST AND INTELLIGENCE QUOTIENTS OBTAINED BY THE NATIONAL INTELLIGENCE TEST OF THE FOURTH. FIFTH AND SIXTH GRADE PUPILS OF THE PORT FULTON SCHOOL OF JEFFEFSONVILLE, IND.

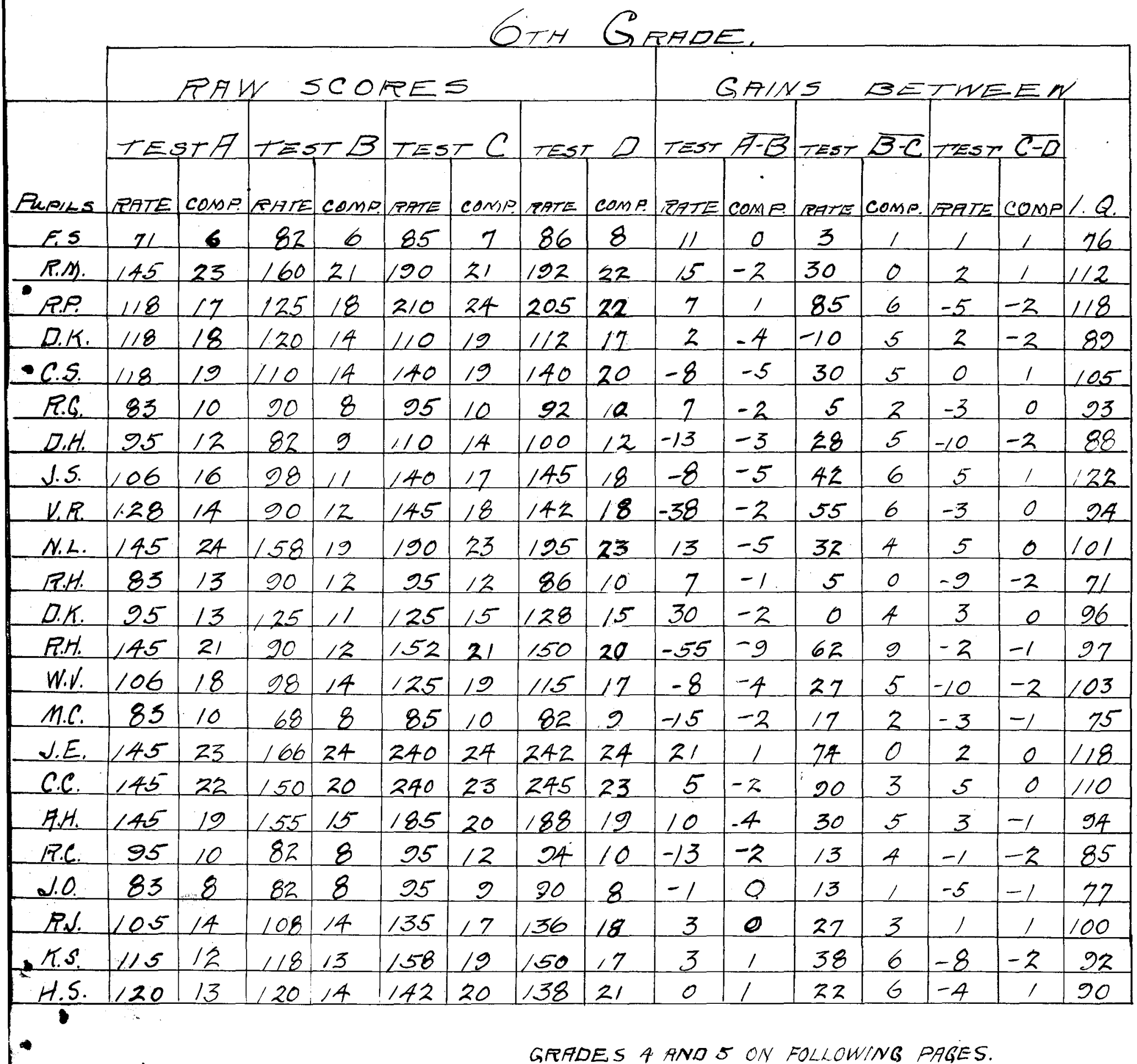


STH. GRADE

RAW SCORES

TEST A TEST 3 TEST C TEST D TEST $\overline{A-B}$ TEST $\overline{B C}$ TEST C-D

PUPILS RATE COMP. RATE COMPIRATE COMP. TATE COMP RATE COMP CATE COMP ICATE COMP LQ

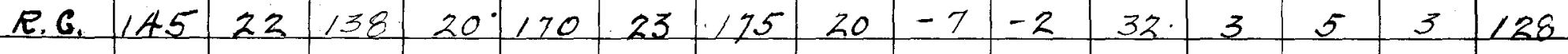

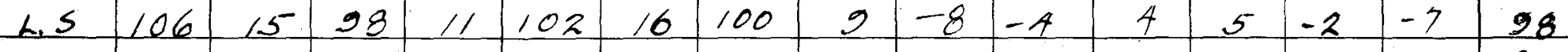
\begin{tabular}{l|l|l|l|l|l|l|l|l|l|l|l|l|l|l|l} 
H.m. & 83 & 5 & 110 & 10 & 112 & 10 & 108 & 11 & 27 & 5 & 2 & 0 & -4 & 1 \\
\hline
\end{tabular} \begin{tabular}{lll|l|l|l|l|l|l|l|l|l|l|l|l|l} 
E.A. & 71 & 8 & 82 & 9 & 95 & 11 & 98 & 11 & 11 & 1 & 13 & 2 & 3 & 0 \\
\hline
\end{tabular} \begin{tabular}{l|l|l|l|l|l|l|l|l|l|l|l|l|l|l|l} 
T.N. & 83 & 4 & 67 & 5 & 65 & 4 & 68 & 5 & -16 & 1 & -2 & -1 & 31 \\
\hline
\end{tabular} \begin{tabular}{llllllllllllllll|l|l|l}
0.1 & 59 & 6 & 68 & 5 & 55 & 7 & 53 & 7 & 9 & -1 & -13 & 2 & -2 & 0 & 100 \\
\hline
\end{tabular} \begin{tabular}{l|l|l|l|l|l|l|l|l|l|l|l|l|l|l|l}
$0 . H$ & 71 & 6 & 80 & 10 & 85 & 10 & 85 & 11 & 9 & 4 & 5 & 0 & 0 & 1 \\
\hline
\end{tabular} \begin{tabular}{l|l|l|l|l|l|l|l|l|l|l|l|l|l|l|l} 
L.M. & 145 & 21 & 138 & 19 & 140 & 23 & 142 & 23 & -7 & -2 & 2 & 4 & 2 & 0 & 120 \\
\hline
\end{tabular} \begin{tabular}{l|l|l|l|l|l|l|l|l|l|l|l|l|l|l|l}
\hline & 55 & 15 & 81 & 11 & 105 & 16 & 106 & 17 & -14 & -4 & 26 & 5 & 12 \\
\hline
\end{tabular} \begin{tabular}{lllllllllllllll|l|l|l|l}
6.0 & 95 & 13 & 94 & 10 & 112 & 13 & 110 & 12 & -1 & -3 & 18 & 3 & -2 & -1 & 92
\end{tabular} \begin{tabular}{c|c|c|c|c|c|c|c|c|c|c|c|c|c|c|}
$C .5$ & 118 & 9 & 92 & 10 & 140 & 15 & 141 & 14 & -26 & 1 & 48 & 5 & 1 & -1 \\
\hline
\end{tabular}

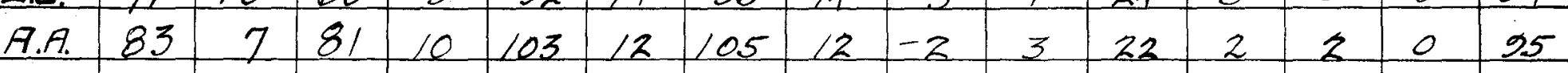

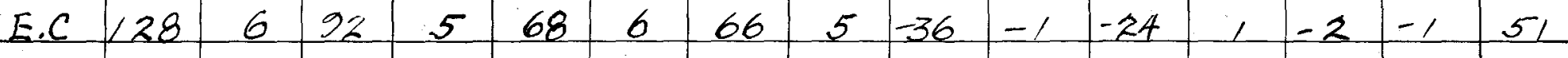
\begin{tabular}{l|l|l|l|l|l|l|l|l|l|l|l|l|l|l|l} 
K.5. & 47 & 1 & 56 & 6 & 68 & 5 & 71 & 6 & 9 & 5 & 12 & -1 & 3 & 1 & 76 \\
\hline
\end{tabular} \begin{tabular}{c|c|c|c|c|c|c|c|c|c|c|c|c|c|c|c} 
C.B. & 59 & 4 & 44 & 6 & 92 & 8 & 92 & 9 & -15 & 2 & 48 & 2 & 0 & 1 & 91 \\
\hline C.5. & 128 & 4 & 81 & 6 & 100 & 8 & 104 & 7 & -47 & 2 & 19 & 2 & 4 & -1 & 84
\end{tabular} \begin{tabular}{c|c|c|c|c|c|c|c|c|c|c|c|c|c|c|c} 
C.5. & 128 & 4 & 81 & 6 & 100 & 8 & 104 & 7 & -47 & 2 & 19 & 2 & 4 & -1 & 84 \\
\hline .5 & 100 & 1 & 130 & 6 & 92 & 4 & 96 & 4 & 30 & 5 & -38 & -2 & 4 & 0 & 41
\end{tabular} 
57

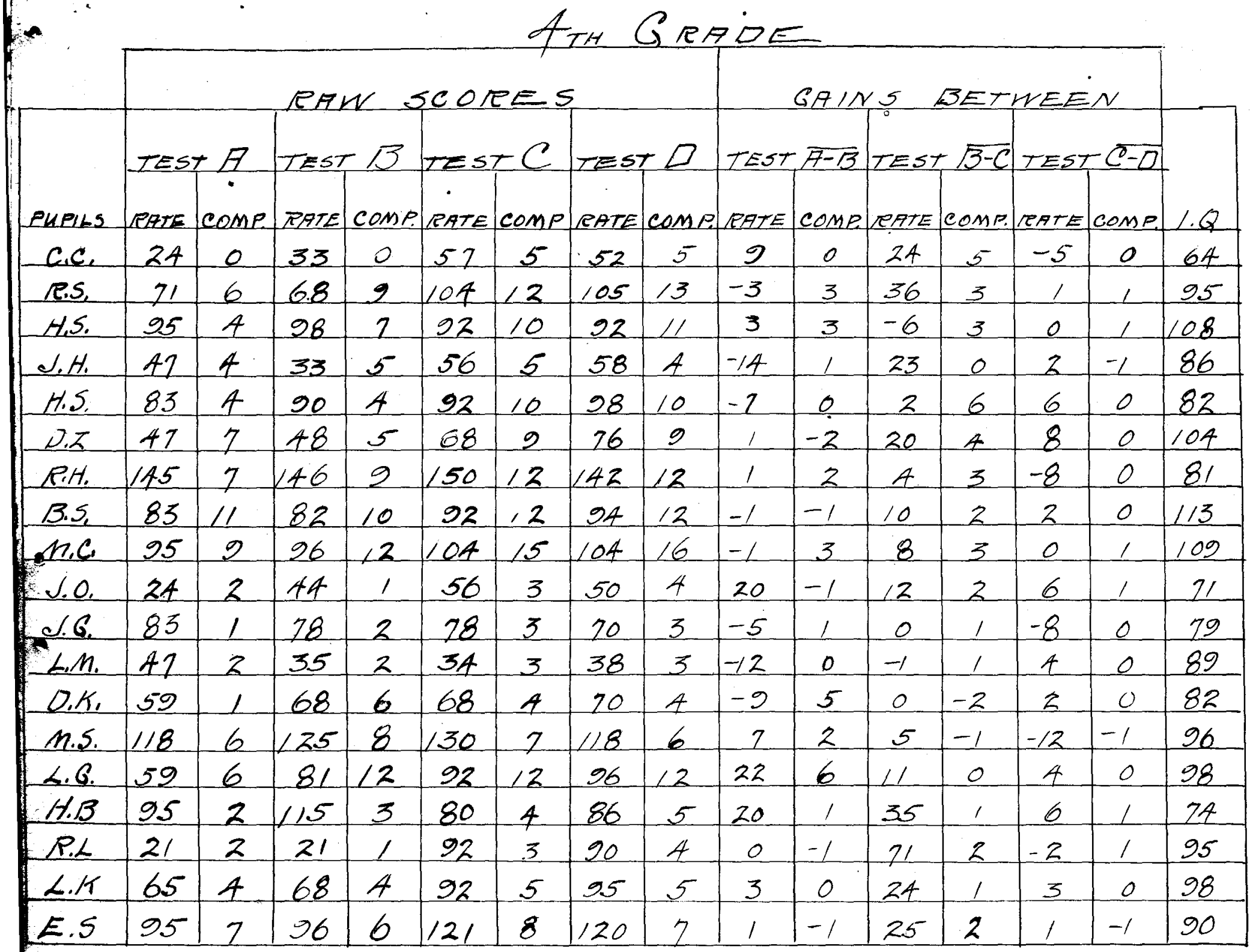


Table showing number of booklets rad per pupil in Grades 4-5-6 of the Port Fulton School of Jeffersonvilie, Indiana.

NUMBER OF BOOKLETS

\begin{tabular}{|c|c|c|c|c|c|c|c|c|c|c|c|c|c|c|c|}
\hline GRADE & 0 & 1 & 2 & 3 & 4 & 5 & 6 & 7 & 8 & 9 & 10. & 11 & 12 & 13 & TOTAL \\
\hline VI & & 1 & 5 & 2 & 1 & 3 & 2 & 2 & 1 & 4 & 0 & 0 & 1 & 1 & 23 \\
\hline V & 1 & 4 & 3 & 1 & 1 & 4 & 2 & 2 & & & & & & & 18 \\
\hline IV & $I$ & 2 & 7 & 6 & 1 & 2 & & & & & & & & & 19 \\
\hline
\end{tabular}

